\title{
EXECUTIVE DEVELOPMENT PROGRAMMES - REQUIREMENTS AND SUCCESS FACTORS
}

\author{
Tobias Cramer ${ }^{*}$
}

\section{Introduction}

According to the evolutionary law of learning, a species will survive only if its rate of learning is at least as large as the rate of change in its environment. This rule also applies to the learning of managers and companies, since competition is - like natural evolution - a process of selection in which those who adapt better and faster are able to secure their existence.

With dynamic market and environmental conditions, Conraths and Plompen ${ }^{1}$ speak of a ,triple hurricane“ namely ,technology drive, globalization and competition”: sustainable competitive advantages are increasingly based on knowledge advantages. While new technologies are available worldwide in a short time, it is the know-how of employees and managers that provides the best and most effective long-term protection from its imitations. Managers are a key success potential and a strategic factor for the management. Therefore, their training is of particular importance. They represent the most important target group for external suppliers, i.e., training offered by specialized institutions outside the company.

Management education is the pursuit of adjustments to new developments and to a deeper understanding of problems and contexts that are used to manage a company. ${ }^{2}$ Executive Development Programmes (EDPs) are a form of management education: they address ,the development of managers and executives at more senior levels within an organization. ${ }^{\text {"3 }}$ In general, EDPs include an overall increase in the competencies of managers, they offer practical state-of-the-art training to acquire new skills and benefit from the experience of other students. "Like Plato's classic allegory of , The Cave', one of the demands of leadership is to persuade individuals who have accepted limited approximations of reality, like flickering shadows on a cave wall, to see greater potentialities for themselves and their world. ${ }^{\text {“4 }}$

The topic of this article is executive development programmes at business schools and other executive education institutes, which in principle are open to all execu-

\footnotetext{
* University of Economics, Prague, Faculty of International Relations (tobias.cramer@vse.cz).

1 Conraths and Plompen, 2000, p. 258.

2 Sauter 1991, p. 9.

3 Crotty and Soule, 1997, p. 4.

4 Fulmer, 1990, p. 26.
} 
tives and offer no academic qualifications (open, non-degree programmes). As it aims to analyse external training for senior executives, the target group of the paper is executives in senior positions.

The paper is divided into five sections. The characterization of senior executives as the target group of EDPs is the starting point. The second part describes the current situation in executive education worldwide. This is followed by the third section, which deals with the requirements for EDPs. In addition to selection criteria and objectives, success factors of the programmes are the main subject of this section. The article concludes with a synthesis of key findings.

\section{Executives as the target group of EDPs}

A concrete definition of an ,executive“ is difficult to draw, because a generally accepted definition does not exist. Moreover, much of the personnel management literature offers differing defining criteria, depending on the core of the analysis. ${ }^{5}$

Ulrich and Fluri understand executives as those, ,who have the formal right to give instructions to other persons; these persons are obliged to follow. "6 ${ }^{\text {In }}$ practice, one differentiates according to the hierarchical position. In the Anglo-Saxon area, distinction is made between top/senior management, middle management and lower management. Top/senior management includes the real top management and upper management. ${ }^{7}$ Senior executives are staff who work directly under the top management. ${ }^{8}$ According to the Anglo-Saxon distinction, in large companies members of the second, sometimes even the third level are also seen as top management. ${ }^{9}$

The target group of senior executives is based on the „Advanced Management Program“ (Harvard Business School) by Pack as individuals who are either already in top management or on the verge of taking over a position in top management. They already have an extensive experience in the management of individual departments or functional areas and move now into the supreme decision-making body of a company. It is crucial to Pack that these executives see the company as a unit and the individual functional areas are not in the foreground. ${ }^{10}$ Also, according to Richter, executives deal with general management questions. While this is limited in SMEs only to the top management level, such positions in large companies and holdings are also at other levels of management. This includes executives who are heads of major functional areas as well as leaders of profit centres or managers of subsidiaries of a parent company required to report directly to the Executive Committee. ${ }^{11}$ The definition

5 Weber, 1997, p. 5.

6 Ulrich and Fluri, 1988, p. 37.

7 Weber, 1987, column 316.

8 Hammer, 1988, p. 26.

9 Gaugler, 1993, p. 69.

10 Pack, 1969, p. 69.

11 Richter, 1992, p. 124. 
of the target group implicitly assumes a stable organizational structure as it is found usually in larger, division-of-labour companies in the industrial and service sectors.

What is problematic, however, is the direct transfer to companies such as the software industry or large consulting firms because of their structural peculiarities. ${ }^{12}$

\section{The Market of Executive Education: An Overview}

The business education sector is perceived to be counter-cyclical - as the economy goes into decline and conditions on the job market become tougher, applications to MBA programmes typically increase. However, this model does not extend to executive education. With funding for executive programmes generally coming directly from employers rather than individuals, revenues can drop off as training budgets are frozen or reduced in reaction to an economic downturn. ${ }^{13}$ The global economic downturn following the financial and economic crises has slowed the industry's growth in the past few years. Schools have seen 2-3 years of painful decline in revenues from executive education programmes. Now they hope that business is returning. But, according to Steve Burnett (associate dean of executive education at Kellogg School of Management at Northwestern University, Illinois) getting back to the glory days of 2006 will take time: executive education "tends to tank fast, then take a few years to recover"; following the terrorist attacks of September 11, 2001, "it took us 4-5 years to dig ourselves out of the hole". ${ }^{14}$ The Financial Times data reveal the extent of the downturn by the decline in the numbers of students between 2008 and 2010 as shown in Figure 1.

\section{Figure 1}

\section{Average numbers of participants per school on open programmes}

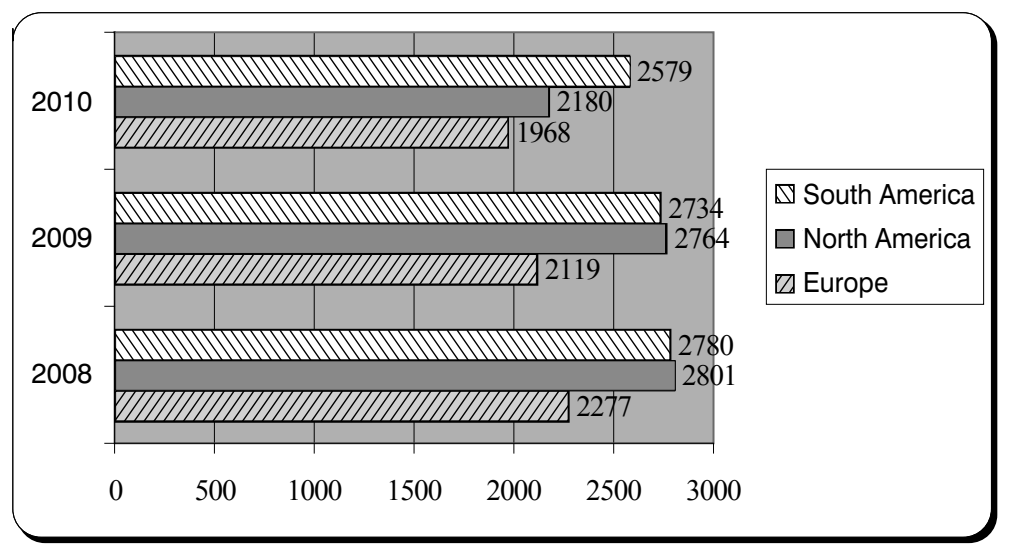

Source: Based on Jacobs, 2010, Financial Times. ${ }^{15}$

12 Weber, 1997, p. 6.

13 Jacobs, 2009.

14 Burnett, in Bradshaw, 2011, p. 8.

15 Jacobs, 2011. 
However, the popularity of university-based executive education around the world still has potential. According to the findings of a study conducted by the Manchester Business School, Dubai International Academic City, and Dubai Knowledge Village, the global economic downturn has had a negative impact on training and development spending within the Middle East. More than half of the respondents noted that spending on executive education had been "significantly" affected, while other organizations agreed that spending had been "somewhat" affected. Dr Lucy Daly, Research Business Manager, Manchester Business School, said: „Development budgets in the region have been hit by the economic downturn, with almost $70 \%$ of respondents stating that budgets had declined over the last three years. However, improvement is expected during the next three years, with around $50 \%$ of respondents expecting spending to increase and only $18 \%$ anticipating a decrease in budgets." ${ }^{16}$

The situation is similar in other parts of the world according to a late 2010 state of the industry survey conducted by UNICON. UNICON is a consortium of 97 worldwide member business schools - including Columbia, University of South Carolina, Notre Dame, Harvard, Stanford, Wharton, London School of Business, and Cheung Kong Graduate School of Business. They found that many universities with executive education programmes around the world expect notably higher enrolment during 2011. Sixty-five percent of the participants surveyed by UNICON predicted increased participation in their open enrolment programmes this year. Additionally, 78 percent of the schools projected an increase in customized executive education programmes during 2011. Nearly half of the schools surveyed indicated an increase in their number of programming days, now offering up to 39 weeks in open enrolment programmes and an average of 49 weeks in custom programmes. Slightly more than half also reported increasing the number of days that educational programmes for executives are offered. "As the survey trends indicate, the executive education industry is in a positive transition as industries rebound and their leaders return for the educational and development opportunities provided by university-based executive education," said Mike Malefakis, Associate Dean for Executive Education at Columbia University and co-chair of the UNICON benchmarking committee responsible for the survey. ${ }^{17}$ The following figure shows the structure of executive education in the United States. 


\section{Figure 2}

\section{Executive education in the US}

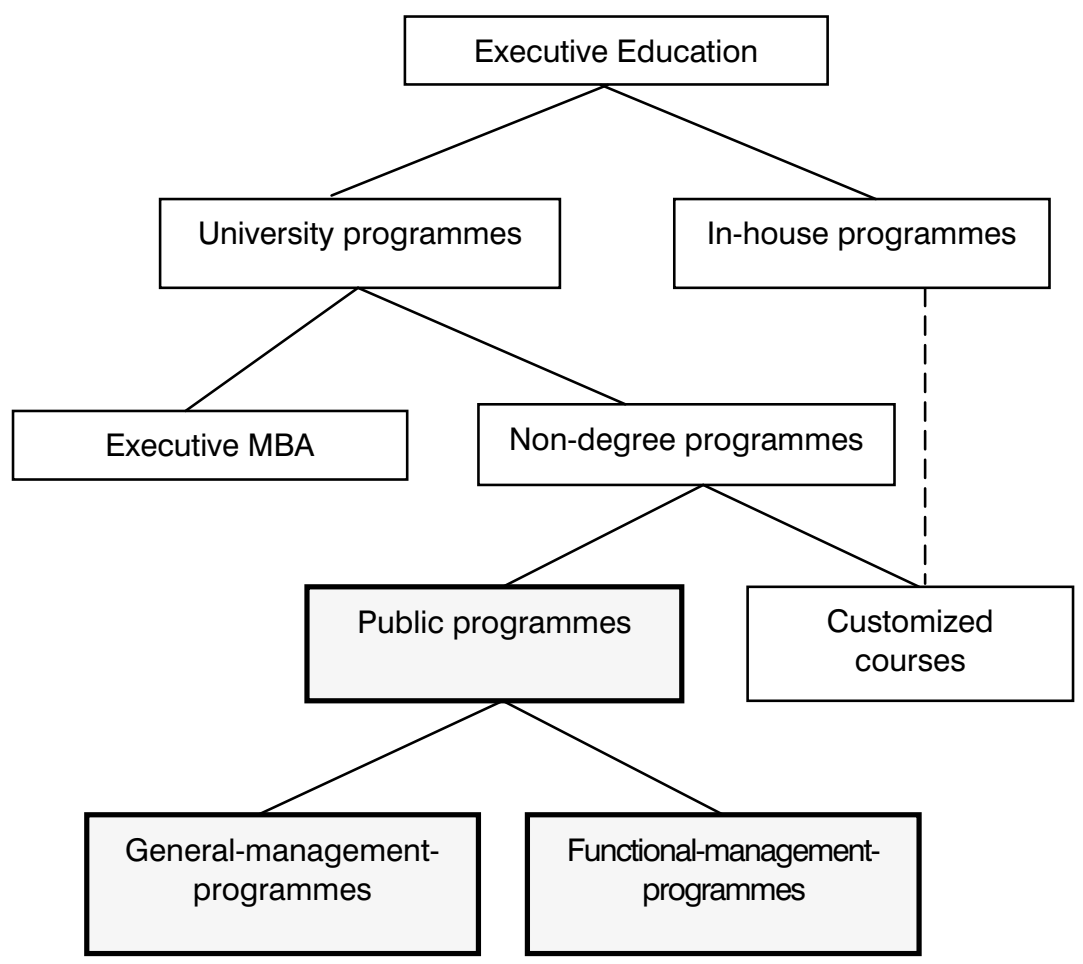

Source: Based on Crotty and Soule 1997, pp. 4.

US companies have been using EDPs for a long time. First developments go back to the late 19 th century and the early 20 th century. As the above classification shows, there are different types of executive development. In addition to companies' internal training initiatives (in-house programmes), universities and their business schools offer executive MBA programmes and a variety of public courses in functional areas or general management. Recently, company-specific programmes (customized programmes) have become increasingly attractive. Bob O'Connor, director of corporate education for the QUT Faculty of Business (Australia), says that due to the global financial crisis there has been a clear move away from long-term general management programmes to shorter, multi-disciplinary workplace-blended learning programmes. They tangibly help organisations execute business strategies or solve business problems. ${ }^{18}$

As illustrated in Figure 3, Harvard University managed to win first place in the field of non-degree executive education according to Business Week's survey 2011; Iese Business School (Barcelona) according to the FT's survey 2011. 


\section{Figure 3}

Top 10 in Open Enrolment Programmes (Executive Education worldwide)

\begin{tabular}{|c|c|}
\hline & The Top 10 Ranked in Executive Education \\
\hline & $\begin{array}{l}\text { 1. Harvard University } \\
\text { 2. INSEAD } \\
\text { 3. Stanford University } \\
\text { 4. IMD Northwestern Univ. (Kellogg) } \\
\text { 5. Centre for Creative Leadership } \\
\text { 6. London Business School } \\
\text { 7. Univ. of Pennsylvania (Wharton) } \\
\text { 8. Univ. of Michigan (Ross) } \\
\text { 9. IESE Business School } \\
\text { 10. Massachusetts Inst. of Technology } \\
\text { (Sloan) }\end{array}$ \\
\hline
\end{tabular}

\begin{tabular}{l} 
The Top 10 Ranked in Executive Education \\
\hline 1. lese Business School \\
2. Harvard Business School \\
3. Thunderbird School of Global \\
Management \\
4. IMD \\
5. Univ. of Virginia: Darden \\
6. London Business School \\
7. HEC Paris \\
8. Essec Business School \\
9. Centre for Creative Leadership \\
10. Fundação Dom Cabral (Brazil)
\end{tabular}

Source: Businessweek 2011, http://www.businessweek.com/bschools/rankings/;

FT 2011, http://rankings.ft.com/businessschoolrankings/executive-education-open-2011.

According to Turpin (IMD), the future of executive education will be shaped by the following trends:

- more demanding customers (efficiency, flexibility, real-time availability, etc.);

- emerging market competitors (organizations from emerging markets starting to compete in the global arena);

- new technology (iPad, podcasts, Twitter, Facebook, blended learning, etc.);

- increasing globalization (organizations need leaders who are comfortable operating in a global context);

- complexity in environment;

- faculty scarcity;

- commoditization of products and services. ${ }^{19}$

19 Turpin, 2011. 


\section{Requirements placed on Executive Development Programmes}

The following chapter deals with the programme requirements from a practice-induced point of view. First, selection criteria and goals are discussed; this is followed by a discussion of the success factors of the programmes; and finally, recent trends in executive education are shortly described.

\subsection{Selection criteria and objectives}

In general, contents, target group and existing own resources determine the choice of an alternative training or a specific school. ${ }^{20}$ To determine a benchmark for the preferability of alternative offers, relevant evaluation criteria and weightings have to be set. ${ }^{21}$ In particular, open programmes, where there are only few opportunities to influence the course design and learning objectives and where content and methods are given, should undergo an examination of whether they fit the corporate goals and the training strategy. ${ }^{22}$ As a result of increased educational awareness and the recognition that executive education supports strategic changes in all areas of the company, appropriate measures have been increasingly selective and focused: „Executive education is now taken very seriously. “23

The price of a programme presents itself as a subordinated criterion: the first priority is quality. HR managers assess the course not according to the promises of its organizers, but primarily the quality of the instructors. ${ }^{24}$

According to Schrader, the programme content, length, objectives, as well as the reputation of the institution and composition of the participant group provide the most important selection criteria for both American and European personnel managers, participants and, moreover, US suppliers. Familiarity with the business school, the price of the seminar, location and intensity of the implementation of the programmes are less important factors. Noteworthy is the fact that the importance of each criterion was rated very similarly. The only exception among the five most important factors was the mention of the composition of the group of participants, which played, for the participants themselves, a subordinate role. ${ }^{25}$

Schwuchow's findings from a survey among companies show the proven quality of institutions as most important. Other criteria are learning content and learning objectives. From the participants' point of view, reasons for attending a seminar are the general reputation of the institution and programmes specifically recommended by third parties, while the uniqueness of the seminar in terms of instructors and teaching methods are not considered decisive. Schwuchow presumes that the reason for this is the low level of the participants' knowledge at the time of application. According

20 Schwuchow, 1992, p. 116.

21 Piontkowski, 1986, pp. 74.

22 Schwuchow, 1992, p. 117.

23 Vicere, 1993, p. R4.

24 Schade, 1997, pp. 132.

25 Schrader, 1985, p. 58 
to Schwuchow, respondents expect a qualification that goes beyond the skills of their current activity. Asked about their objectives, 79\% of the executives seek a general expansion of their existing knowledge. For $75 \%$, learning new methods and tools for specific work situations were of particular significance. ${ }^{26}$

A study conducted in the US revealed that for $90 \%$ of the surveyed companies, the reputation of the institute and the teaching faculty was the most important aspect of selection. This was followed by experience exchange with $85 \%{ }^{27}$

According to Sauter, the most important factors in choosing an executive development programme are practice orientation, experience exchange and future orientation. There, factors such as prestige and reputation of the institution, reputation of the faculty, international orientation and the number of participants also play a significant role. A comprehensive range of courses, fees and career plans receives no significance. ${ }^{28}$

Personal/corporate experience with the provider and offering transfer of supporting instruments and measures, according to the experts in a study by Voss, stand at the forefront of decision-relevant criteria. In open programmes, growing interest is given to the international composition of the group of participants. In particular, for the top management the image and the international orientation of the school play a major role. Furthermore, in this target group a greater emphasis is placed on learning environment and atmosphere. ${ }^{29}$

Schrader's study conducted in the US revealed that $90 \%$ of the surveyed personnel managers noted that ,broadening the individual and showing the big picture“ is a goal for executives. Another important goal, stated by $58 \%$, was being given the opportunity for senior executives to meet with other executives to learn from their experience. This underlines the importance of sharing experience in an executive development programme. Still, $45 \%$ and $44 \%$ of the human resource managers, respectively, thought it important to get specific new information or improve their problem-solving skills and decision-making process. In essence, these targets were consistent with those that the participants agreed on, both to differing views regarding the criterion „Getting away from it all" at external seminars. While $57 \%$ of the executives saw this factor as important, only $31 \%$ of HR managers did so too. ${ }^{30}$

\subsection{Success factors}

Success factors are characteristics that are largely responsible for the success of Executive Development Programmes. In the following, success factors and requirements will be regarded as the same.

26 Schwuchow, 1992, pp. 203.

27 Fulmer, 1988, pp. 269.

28 Sauter, 1991, pp. 261.

29 Voss, 2000, pp. 16.

30 Schrader, 1985, p. 55. 


\subsubsection{Overview}

Numerous attempts exist in the literature to generate the success factors of external training events for senior executives. First, general statements about requirements for EDPs will be made, before a particular model is applied.

A study by the Wall Street Journal and Bricker identifies some EDP outcome as particularly important: effectiveness, improving the skills of participants regarding their ,ability to innovate and think in new ways, ..., leadership role, ..., personal skills and career potential."31 Also the initialization of contacts and networks, which both the participants and the companies can benefit from, has a significant role. According to Porter and McKibbin too, this represents a significant success factor; others were the introduction of new ideas and the generally very high quality and prestige of the institution. $^{32}$

Schwuchow differentiates criteria for success in a study with external managers from the training providers' point of view in the US and Europe as well as from the participants' point of view. Providers in Europe regarded the instructors as most important, followed by the composition of participants. The mix of teaching methods, the possibility of experience exchange, a learning environment that allows a distance from everyday responsibilities, as well as the duration of the seminar are further important success factors. However, in practice the various criteria cannot be viewed in isolation. A fundamental difference to the European assessment is the importance of exchanging experience that has been categorized by the major American institutions as more important to any other criteria. This underlines the importance of experiential learning, the focus of EDPs not on teaching, but on exchanging experience. ${ }^{33}$ From the perspective of participants the exchange of company and cross-industry experience is named in the first place along with the instructors. The experience exchange includes active exchange of ideas and discussion of topics, which do not affect their current position as well as offer suggestions for their own actions, and improve their decisionmaking and judgment skills. ${ }^{34}$ Other key criteria are the teaching methods and the mix of participants. The composition of the group of participants is viewed as more important than the number of participants. Comparatively less important for the participants were conditions and duration of the seminar. The duration of the seminar, which the European providers and participants classified similarly, plays a much larger role for American suppliers. This may be due to the more time-restricted approach to education programmes in the US: ,the currency is time, not money. “" ${ }^{\text {"35 }}$

The participants' survey creates a basis for Schwuchow's success factor model by using factor analysis which extracted four assessment dimensions. This allows a classi-

31 n.a. 1993, p. R8.

32 Porter and McKibbin, 1988, p. 272.

33 Schwuchow, 1992, p. 213.

34 ibid, p. 215.

35 White, 1992, p. 217. 
fication of criteria based on a simple structure. ${ }^{36}$ As can be seen in the figure below, these four factors extracted explain only $57 \%$ of the variance in the original variable. Nevertheless, they allow us to uncover content-based relations.

\section{Figure 4}

Success factors for external executive training from participants' view

\begin{tabular}{|c|c|c|}
\hline Construct & $\begin{array}{l}\text { Variance explanation } \\
\text { (accumulated) }\end{array}$ & Factors \\
\hline Provider quality & $24.9 \%$ & $\begin{array}{ll}\text { - } & \text { Reputation } \\
\text { - } & \text { Instructors } \\
\text { - } & \text { Teaching methods } \\
\text { - } & \text { Theoretical level }\end{array}$ \\
\hline $\begin{array}{l}\text { Experiential learning and } \\
\text { internationality }\end{array}$ & $37.6 \%$ & $\begin{array}{l}\text { - Exchange of experience } \\
\text { - International orientation } \\
\text { - Future orientation }\end{array}$ \\
\hline Applied approach & $47.6 \%$ & $\begin{array}{l}\text { - Practical relevance } \\
\text { - Problem-solving tools } \\
\text { - } \text { Group of participants }\end{array}$ \\
\hline Environmental conditions & $57.4 \%$ & $\begin{array}{l}\text { - Seminar duration } \\
\text { - Learning environment }\end{array}$ \\
\hline
\end{tabular}

Source: Based on Schwuchow 1992, p. 220.

The success factors of this model will now serve as the basis for a differential treatment of the requirements for EDPs.

\subsubsection{Provider quality}

The quality of the provider is composed of the factors of reputation of the institute, together with its instructors, teaching methods and theoretical level.

The reputation of the business school or training institution is both a criterion of selection of EDPs and the determination of success in the competition as well. Often, the reputation of the institution is transferred to the quality of the courses. This approach is supported by various rankings which continuously put the same business schools among the top 10. These regularly include, as described in Chapter 2, the institutions of the "Ivy League“ in the United States, which have succeeded in the past to transfer the reputation of their graduate education (MBA) to the field of executive education. It should be noted, however, that there are significant differences in these rankings with respect to the disciplines. Thus, although the Harvard 
Business School (HBS) as a whole and in general management is set at number one, it cannot be found in the top five institutions in Executive MBAs, for example. EDPs are based on market-proven, standardized concepts that allow a consistent quality. ${ }^{37}$ No value is placed on obtaining an academic degree; corresponding interests can be found only at the lower management level. ${ }^{38}$ The waiting lists for EDPs are long, which allows the organizers to control the admission. This not only contributes to the elitism of the institutions concerned, but is consciously used to comply with the requirement of a reasonable experience exchange.

It should be noted once again that both suppliers and participants agree that the quality of the instructors is the most important success factor. This means all institutions pay attention to the special quality of its teaching staff in their informational materials, so for example, we read of ,the unparalleled expertise of Harvard Business School faculty". ${ }^{39}$ The instructors are responsible for communicating the contents of EDPs, using appropriate teaching methods to enable participants to achieve the training objectives. Regarding the practical relevance, it is important whether the institution operates with a staff of tenured professors or with employed lecturers from academia and practice..$^{40}$ The use of one's own faculty facilitates the coordination and integration of the seminar units and ensures a consistent quality, but it also restricts the flexibility and possibly the width of the mediated content. Ultimately, it depends on the right ,mix “ of what is being developed by the theorist, is made more interesting in the lecture with the practitioner's remarks, and thus remains in the memory. On the other hand, versions by practitioners are conceptually analyzed and placed in a more complex context by university professors. Basically, business schools employ approximately $10 \%$ of their staff as professors from other universities and established practitioners. ${ }^{41}$ Here, the teaching staff are recruited mainly from their own country, according to a study by Gerlach. ${ }^{42}$

In spite of the supplement by practitioners, the faculty is generally asked not only to operate in teaching and research, but also to engage in practice. So teachers at HBS are „distinguished academicians and business leaders, they also excel as board members, management consultants, government advisors, researchers, and authors of cutting-edge publications. “43

General management programmes require the largest number of instructors as they reflect the broad problems of corporate governance to consult economic experts from theory and practice, politicians and other external speakers. There are about 90 instructors at the USW* and the London Business School ${ }^{44}$, while 30 lecturers teach

37 Schade, 1997, p. 142.

38 Murphy and Tang, 1993, p. 186.

39 n.a. 2011 e, p. 7.

40 Schwuchow, 1992, p. 118.

41 Fulmer, 1997, p. 59.

42 Gerlach, 1992, p. 59.

43 n.a. 2011e, p. 7

44 Schade, 1997, p. 132. 
for the Advanced Management Programme at the Wharton School only. ${ }^{45}$ Basically, fewer efforts go towards functional programmes if they use an average number of eight. ${ }^{46}$ The instructor increasingly takes the role of a facilitator especially when working with case studies or simulations. ${ }^{47}$ Also with the application of new learning media the role of the teacher is changing to that of a coach or tutor. ${ }^{48}$

The right mix of teaching methods plays a decisive role for a successful executive development programme in both the discussions in the literature as well as the results of studies. The teaching method mix has not changed, according Schwuchow: the case method prevails especially in the US, while in Europe simulations and workshops are also being used. ${ }^{49}$ It should be noted, however, that the use of different methods is often institution-specific. Thus, the case study method at Harvard (which is ultimately responsible for the construction of this method) is the primary form of mediation, the participants obtain the advantage ,of being taught by many of the same faculty who actually developed the particular cases." ${ }^{\text {"50 }}$ The lack of concrete projects sometimes is, to a certain extent, due to the fact that American business schools are part of the university system, while the majority of European providers operate as management training and further education institutions. ${ }^{51}$

A study by human resource managers with Staehli shows that the case study method was deemed most important for an effective and efficient communication of the learning content. As with Schwuchow, the lecture method is attributed little significance in this context. It remains to be noted that (pro)active learning/teaching methods are most important. According to Staehli, a case study is suitable if it was especially developed for the target audience and designed in a holistic and system-oriented way, allowing a lateral transfer from the field of learning (learning process) into the function field (management practices) and also takes into account ethical and environmental issues. ${ }^{52}$ The following figure provides information about the teaching methods used at the London Business School (LBS).

45 n.a. 2011f, p. 5 .

46 Schade, 1997, p. 133.

47 Pieper, 1989, p. 58.

48 Gorhan, Kerr and Mahringer, 1998, p. 107.

49 Schwuchow, 1992, p. 208.

50 n.a. 2011e, p. 10.

51 Monte Robl, 1992, in Schwuchow et al., 1994, p. 266.

52 Staehli, 1990, p. 40. 


\section{Figure 5}

Mix of teaching methods at LBS (blended learning)

\begin{tabular}{|l|l|l|}
\hline Traditional & Peer Group & Technology-Based \\
$\begin{array}{l}\text { Lectures, Case Studies, } \\
\text { Senior management input, } \\
\text { Guest speakers, Debate }\end{array}$ & $\begin{array}{l}\text { Group exercises, } \\
\text { Brainstorming, Networking, } \\
\text { Participative learning methods, } \\
\text { Peer consulting, Outdoor } \\
\text { training }\end{array}$ & $\begin{array}{l}\text { Simulations, Distance learning, } \\
\text { E-mail, Video conferencing, } \\
\text { Lotus Notes, Computer-based } \\
\text { teaching }\end{array}$ \\
\hline $\begin{array}{l}\text { Action-Oriented } \\
\begin{array}{l}\text { Project-based, Action learning, feedback and follow-up, } \\
\text { Individual action plans, Group } \\
\text { action plans }\end{array}\end{array}$ & $\begin{array}{l}\text { Eenchmarking } \\
\text { Investigative learning }\end{array}$ & Broadening \\
\hline
\end{tabular}

Source: Based on Conraths and Plompen 2000, p. 261; LBS brochures.

Another important trend is the increased use of distance learning. It is not a new concept though. For several decades, it has received the necessary attention according to the postulated self-responsible learning process in adult education with experienced individuals. ${ }^{53}$ With distance learning, time and place-independent learning are possible. Over spatial distances, a large number of learners can continue to study flexibly „on demand“, with the simultaneous elimination of seminar-related absences and travel expenses. A higher efficiency of training seminars due to lower costs, faster training, better individual training and shortening the phases of presence seems to be reached thanks to new technologies. ${ }^{54}$

Regarding the objective of using web-based learning, five levels can be distinguished for EDPs:

- communication between instructors and participants,

- online distribution of teaching materials,

- conducting assessments and needs analysis,

- downloadable computer learning programmes, and

- online multimedia learning. ${ }^{55}$

It can be observed that new learning technologies in Executive Development are currently applied primarily for the mediation of standardised skills and are capable of refreshing and updating knowledge. They are mainly used for executive MBAs.

53 Crotty and Soule, 1997, p. 16.

54 Behrendt, 1998, p. 23.

55 Schwuchow, 2000, p. 36. 
However, they still encounter their limits when it comes to the expression of social and sometimes also conceptual skills.

This circumstance has placed a special value on the institutions of executive education: „We are using IT [rather] to complement [than] to replace face-to-face teaching. IT will have a great impact on knowledge transmission, but it cannot replace the exchange of experience. ${ }^{\text {"56 }}$

Although the practical relevance is seen as a central criterion of success, a certain theoretical level is also an important quality indicator of EDPs. For the provider, this implies a link between theory and practice, with both the applicability of the seminar topics and conceptual connections among them. ${ }^{57}$

\subsubsection{Experiential learning and internationality}

Although the relevance of experiential learning in EDPs has already been pointed out, it should be noted once again that the exchange of experience is highlighted in particular also with regard to the sustainability of the learning success and largely determined by the composition of the group of participants and the applied learning methods and the learning environment. ${ }^{58}$ As shown above, the executive learning process is a "learning on models" enabled by the intensive experience often given in a diverse professional background. Participants usually spend most of the seminar together, but interaction between them continues even after the actual teaching. So the executives participating at LBS make presentations at lunch ${ }^{59}$ or discuss their business experience and make comparisons across different business practices at HBS. ${ }^{60}$ Learning takes place not only during the actual duration of the seminar, but goes well beyond it with the formation of social networks. Stanford School of Business has now welcomed far more than 10,000 executives from around the world at its executive programmes and developed valuable professional connections, ,that enable [students] to continue the learning process for the rest of the career and foster personal bonds that span many organizations and cultures". ${ }^{61}$ These networks also follow the call for lifelong learning and provide synergy effects by learning from best practice examples and also the establishment of appropriate organizational contacts beyond the individual development of leadership.

Like other parts of the criteria for success, internationality is multidimensional because it is not only determined by the content design, but also by the composition of participants and lecturers as well as the learning methods and environment. Regarding the learning environment it can be observed that some schools are expanding their seminars beyond the national borders. For instance, the University of Virginia Darden School of Business announced the launch of its new MBA for Executives Global (GEMBA)

\footnotetext{
56 Cavallé, Dean of IESE, Barcelona 2000, in Conraths, Plompen 2000, p. 262.

57 Schwuchow, 1992, p. 222.

58 Schwuchow, 1994, column 97.

59 n.a. 2010c, p. 13.

60 n.a. 2011e, p. 9.

61 n.a. 2010a, p. 10.
} 
programme, in which two-week residencies will take place in several countries around the world, including India, China and the United States. "Darden's [...] faculty will travel to each location with students to provide the highest quality educational experience and to reinforce overarching themes from one locale to another," said Peter Rodriguez, Darden's Associate Dean for International Affairs. ${ }^{62}$ Between modules, GEMBA students will continue to learn via online distance learning tools.

Future orientation also reflects the desire to reflect current knowledge acquisition, which is named by the participants as the primary goal of training. ${ }^{63}$ In this context, Fulmer criticized the case study method, because it is usually linked to the past. He urges for future-oriented scenarios, in which participants raise their awareness regarding the future impact of their actions on the present specific business environment. ${ }^{64}$

\subsubsection{Applied approach}

The applied approach is based on the model of Schwuchow through practical relevance, state-of-the-art problem-solving tools and the group of participants. Basically there is a dilemma between the communication of practical and theoretical concepts, problem solving and knowledge transfer. ${ }^{65}$ Besides the content here, a balance can be created by using different methods. If the teaching of theoretical principles and overall context is in the foreground, then the lecture method is suitable together with self-studying. The teaching of practical concepts is done by the exchange of experience and discussions as well as a greater problem-solving orientation with practical relevance supported by projects, workshops, group work and case studies. These learning and teaching methods secure a lasting learning success. Thus, for once there is no universally appropriate teaching method; rather, it is derived from the intended educational goals. ${ }^{66}$ Furthermore, there is an increased practical relevance through the systematic inclusion of speakers from the corporate world as well as through appropriate projects, which take up the concrete problems of the companies involved. ${ }^{67}$

The question of the group of participants is not only a success factor, but, as illustrated, it is also an important selection criterion. All institutions advertise with the exclusivity of their former attendees. The Harvard Business School, for example, gives information on the management experience/function, geographical location and the size of the sending company and its industry affiliation. While in a German EDP, 20 to 40 participants are usually involved, the number of participants at American events is much higher. So the Senior Executive Programme at Stanford University brings up to 150 participants together. ${ }^{68}$ The organizers divide the executives in groups

\footnotetext{
62 n.a. 2010b, p. 132.

63 Schwuchow, 1992, p. 219.

64 Fulmer, 1997, p. 65.

65 Schwuchow, 1992, p. 250.

66 Ibid, p. 257.

67 Schwuchow, 1994, p. 265.

68 Schade, 1997, p. 140; n.a. 2010a, p. 10.
} 
of five to ten people, where tasks and case studies are handled, role plays organized and freely discussed. Presentations and lectures will be held in plenary. Within the group, the largest possible variety of insights will be taught. Different functions, industries and nationalities are united in a team that is re-formed more than once in long-lasting programmes.

American business schools only accept participants who are nominated and financed by a sending company. One focus of the selection of participants is not on the executive's education or academic degree, but on their practical management experience. So up to 20 years of professional experience is required for Senior Executive Programmes. In almost all institutions it is assumed that the participants have very good knowledge of English.

\subsubsection{Environmental conditions}

Among the environmental conditions are the duration of the seminar and the learning environment. The duration of a training programme has already been mentioned as a critical factor for companies. Depending on the content objectives, the duration of a seminar is from a few days to several weeks. Although learning is a long-term process that requires a certain time, the market for several weeks of seminars is very limited. A reduction in the duration of the seminar is a direct response to demands from executives for shorter courses, as several studies state. ${ }^{69}$ In addition to shortening programmes, the division of programmes into modules is another solution offered by many institutions. Modular programmes allow participants to combine seminar-based learning with practical work experience and thus increase the transfer of learning.

For example, in the nine weeks of the International Senior Executive Programme at HBS, students have to work through about 3,000 pages of case studies. ${ }^{70}$ The seminars often begin at eight o'clock, and last, interrupted by a one-hour lunch break, until the early evening. Participants usually stay in special, simply furnished facilities on the business school campus and are encouraged to stay on the spot for the entire duration of the seminar. Classes are held six days a week, except Sundays to allow participants to rest and prepare for the next week. Optionally, there are a few days for leisure in general management programmes. At the end of the general management courses, the institute usually organizes partner programmes to facilitate their transition into everyday life and to involve relatives in the transfer process. The "partners" programme at the Wharton School for example, ,features abbreviated versions of actual course material, as well as social activities, facilitates the re-entry process and ends the programme on a high note. ${ }^{\text {"71 }}$

The learning environment is of particular relevance to executives, so they often have their own learning centres, designed according to current educational criteria and equipped with modern technology. They have access to libraries and research labora-

69 Voss, Häring and Welge, 2000, p. 12; Murphy and Tang, 1993, p. 186.

70 Schade, 1997, p. 142.

71 n.a. 2011f, p. 8. 
tories, various sports facilities as well as WIFI everywhere. The price of American EDPs usually includes the accommodation and meal expenses. After completing the training they become members of large alumni organizations, with whom regular meetings are held.

\subsection{Newer concepts in Executive Education}

Seminar modules are now offered by all business schools. There is always a connection between on-the-job learning and off-the-job training. A special form of modular courses are part-time programmes; particularly MBA programmes and company-specific seminars are designed for this type of executive education. In addition, corporate universities also offer similar programmes. There is an expectation that in the longer term business schools will have to move away from open programmes. Increasingly, individuals seek a programme that offers a recognized qualification, such as an MBA or EMBA or a Master's degree, while business clients prefer a more customized option for their delegates. ${ }^{72}$

There is a fusion of education and consulting services („,consultraining“). Executive Development is joined with specific consulting and implementation at work. ${ }^{73}$

Finally, joint programmes, which target a limited number of enterprises, combine the advantages of open and company-specific seminars, by enabling inter-company exchange of experience and simultaneously stronger company-related aspects. In addition to business-to-business partnerships, alliances between business schools gain importance $^{74}$ : for example, a collaboration was formed by Columbia Business School and Kellogg Management School under a programme for Deloitte \& Touche, due to the increased demand for instructors. And it is not just education providers that are delivering customised education/training programmes within businesses. Consulting firms engaged in advice on strategic policy issues are often taking a more active role in guiding businesses through the whole process of strategy development and implementation by developing tailor-made internal training programmes. ${ }^{75}$

\section{Conclusion}

The paper aims to analyse requirements and success factors in external training for top executives. Based on the findings determined above, the following illustration (Figure 6) is designed for a summary.

72 Lamming, 2010, p. 13.

73 Schwuchow, 2000, p. 37; Schwuchow, 1992, p. 199.

74 Reingold, 1997, p. 66.

75 Unkles, 2004, p. 3. 


\section{Figure 6}

\section{Set of factors regarding successful EDPs}

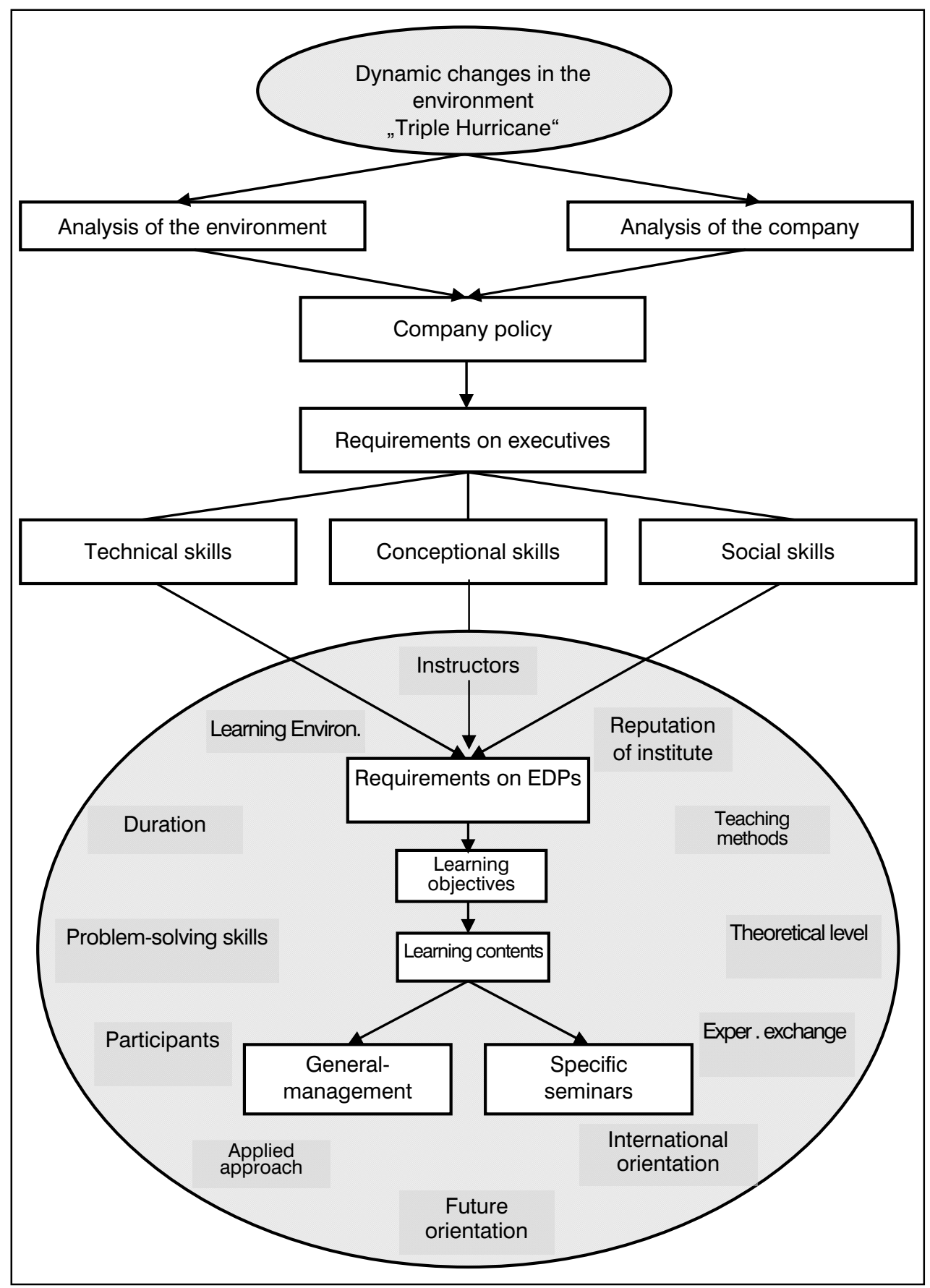

Source: compiled by the author. 
Against the backdrop of rapidly changing conditions of economic activity, explored through the analysis of the environment and the company, requirements for executives can be derived based on a company's policy, far more cross-functionally than before. Further education institutions have the task of satisfying the demand for teaching technical, conceptual and social skills in compliance with the requirements of the learning process and type of content.

It can be noted at this point that the surveyed institutions are aware of the demands. A practice-induced model has been employed for the identification of the success factors of EDPs; it identified the following success factors, some interdependent:

Provider quality, i.e., reputation of the institute, teaching methods, instructors, theoretical level;

Experiential learning and internationality, i.e., exchange of experience, international orientation, future orientation;

Applied approach, i.e., practical relevance, problem-solving tools, group of participants;

Environmental conditions, i.e., duration of the seminar, learning environment.

Taking the learning process of senior executives into account, i.e., in particular model learning (or identification learning), all the institutions studied offer the opportunity to participate in an active corporate and cross-industry exchange of experience with executives at the same management level. To create the possibility for a reasonable exchange of experience, the institutes follow a strict registration policy. At the same time, this leads to the formation of social networks, both of which benefit the executives and the company they come from.

Another basic principle of adult learning is reflected in the EDPs with the confrontation with one's own managing process (practical relevance), a reasonable quality of the instructors with regard to content and pedagogical skills and the application of modern, active forms of learning. In connection with a more customer-oriented approach and using a modern teaching method mix, not the instructor but the learning executive himself is at the centre of the seminars. The teacher takes the role of a learning consultant and facilitator in preferred methods such as case studies, group work, projects and workshops. To ensure the future orientation of the seminars, possible future scenarios are chosen as the basis of the content. The application of distance learning methods is currently limited to a complementary function, because the disadvantages outweigh the benefits in the field of executive development as the possible interaction of participants is limited. Other success factors are the learning environment, the teaching of current problem-solving tools and an adequate theoretical level. Executive education can no longer be an isolated series of continuing education or even an incentive for individual executives. The institutes will have to ensure a more integrative rather than functional approach, more customer-specific rather than general concepts, as well as new ways of consulting. Alliances between providers, networks and benchmarking will establish themselves, EDPs will build on new teaching methods, relationship marketing, and ultimately the need for lifelong learning. 


\section{References}

BEHRENDT, E. Veränderungen hängen vom Menschen ab: Neue Lernkonzepte in der Aus- und Weiterbildung. In NISPEL, A.; STANG, R.; HAGEDORN, F. (ed.). Pädagogische Innovationen mit Multimedia, 1. Analysen und Lernorte. Frankfurt (Main), 1998, pp. 23-28. ISBN 3933222052.

BRADSHAW, D. The customer becomes king. Financial Times - Business Education. Executive education rankings 2011. 9 May 2011. pp 8-10.

CONRATHS, B.; PLOMPEN, M. International management development: Trends and perspectives. In WELGE, M. K.; HÄRING, K.; VOSS, A. (ed.). Management Development - Praxis, Trends und Perspektiven. Stuttgart, 2000, pp. 257-273. ISBN 3791015605.

CROTTY, P. T.; SOULE, A. J. Executive education: Yesterday and today, with a look at tomorrow. Journal of Management Development. 1997, vol. 16, issue 1, pp. 4-21.

FUCHSBERG, G. Taking control. The Wall Street Journal Eastern Edition. 10. 09. 1993, pp. R1-R4.

FULMER, R. M. The evolving paradigm of leadership development. Organizational Dynamics. 1997, issue Spring, pp. 59-72.

FULMER, R. M. Executive learning as a strategic weapon. Executive Development. 1990, vol. 3, issue 3, pp. 26-28.

FULMER, R. M. Corporate management development and education: The state of the art. Journal of Management Development. 1988, vol. 7, issue Summer, pp. 57-68.

GAUGLER, E. Personalpolitische Funktionen im Top-Management. In WÜRTELE, G. (ed.). Lernende Elite: Was gute Manager noch besser macht. Wiesbaden, Frankfurt, 1993, pp. 69-89. ISBN 3409191771.

GERLACH, K. Projektstudie Managementinstitute in Europa Teil 2. In WITTKÄMPER, G. W. et al. (ed.). Trends and Developments in European Executive Education [USW-Working-Paper 1/92]. Erftstadt, 1992, pp. 51-75.

GORHAN, E.; KERRES, M.; MAHRINGER, M.-L. Lernstatt der Zukunft: Tele-Akademie der Fachhochschule Furtwangen. In NISPEL, A.; STANG, R.; HAGEDORN, F. (ed.). Pädagogische Innovationen mit Multimedia, 1. Analysen und Lernorte. Frankfurt (Main), 1998. pp. 107-119, ISBN 3933222052.

HAMMER, R. Aus- und Weiterbildung von Führungskräften in der Unternehmenspraxis - Leitfaden für Klein- und Mittelbetriebe. Wien : Ehningen, 1988. ISBN 3816902634.

JACOBS, M. 7 May 2010. A hard year for open enrolment, but hope ahead. www.ft.com. 19. 8. 2011.

JACOBS, M. 11 May 2009. Spending - Brakes applied in North America. www.ft.com. 19. 8. 2011.

LAMMING, R. New customer demands: executive education, including in-company programs. Proceedings of the 18th CEEMAN Annual Conference, 23-25 September 2010, Caserta/Naples, Italy, pp. 13-15. ISBN 978-961-92270-5-3.

MURPHY, W. H.; TANG, S. S. Executive development programs: Insights for planners and administrators. Journal of Education for Business. 1993, vol. 68, issue 3, pp. 184-189.

N.A. 2011a. Businessweek. www.businessweek.com/bschools/rankings. 6. 9. 2011.

N.A. 2011b. Financial Times. http://rankings.ft.com/businessschoolrankings/executive-educationopen-2011. 25. 9. 2011.

N.A. 2011c. www.zawya.com/story.cfm/sidZAWYA20110228112046?q=TECOM\%20 Research. 6. 9. 2011.

N.A. 2011d. http://uniconexed.org/in-the-news/c-change-strategies-03-05-2011.html. 6. 9. 2011.

N.A. 2011e. Harvard Business School Executive Education: Advanced Management Program. Boston, 2011.

N.A. 2011f. The Wharton School: Advanced Management Program. Philadelphia, 2011.

N.A. 2010a. Stanford Graduate of Business: Stanford Executive Program. Stanford, 2010.

N.A. 2010b. University of Virginia; Darden School of Business Launches New MBA for Executives Global Program. China Weekly News. 28. 9. 2010, p. 132. 
N.A. 2010c. London Business School: Senior Executive Programme. London, 2010.

N.A. 19. 10. 2009. Educating executives. www.hcamag.com/resources/learning-and-development/educating-executives/115481. 6. 9. 2011.

N.A. Report card. The Wall Street Journal. 10. 9. 1993, p. R8.

PACK, L. Ausbildung und Weiterbildung von Führungskräften an amerikanischen und deutschen Universitäten. Wiesbaden, 1969.

PIEPER, R. Business Schools in den USA. Berlin; New York, 1989, p. 58. ISBN 3111787855.

PIONTKOWSKI, M. Evaluating the seminar marketplace. Training and Development Journal. 1986, vol. 40, issue January, pp. 74-77.

PORTER, L. W.; MCKIBBIN, L. E. Management Education and Development: Drift or Thrust into the $21^{\text {st }}$ Century. New York, 1988. ISBN 0070505217.

REINGOLD, J. Global business goes to school. Business Week. 1997, Oct 27, pp. 64-67.

RICHTER, H. Zielgruppe Obere Führungskräfte. In SCHWUCHOW, K.; GUTMANN, J.; SCHERER, H.-P. (ed.). Jahrbuch Weiterbildung 1992. Düsseldorf, 1992, pp. 124-126.

SAUTER, E. Management Weiterbildung für obere Führungskräfte. Handelswissenschaftliches Seminar: Mitteilungen aus dem Handelswissenschaftlichen Seminar der Universität Zürich. 1991, vol. 174, Zürich 1991.

SCHADE, M. Management-Programme: Garanten systematischer Weiterbildung. In GRAF, J. (ed.) et all. Seminare 1997 - Das Jahrbuch des Management-Weiterbildung. Bonn, 1997, pp. 131-143. ISBN 3931488985.

SCHRADER, A. W. How companies use university-based executive development programs. Business Horizons. 1985, vol. 28, issue March-April, pp. 53-62.

SCHWUCHOW, K. Vom isolierten Seminarereignis zum Bildungsprozeß: Perspektivenwechsel in der Management-Entwicklung. In WELGE, M. K.; HÄRING, K.; VOSS, A. (ed.). Management Development - Praxis, Trends und Perspektiven. Stuttgart, 2000, pp. 25-41. ISBN 3791015605.

SCHWUCHOW, K.; SIMON, H. (ed.). Management-Lernen und Strategie. Stuttgart, 1994. ISBN 3820206999.

SCHWUCHOW, K. Weiterbildungsmanagement: Planung, Durchführung und Kontrolle der externen Führungskräfteweiterbildung. Stuttgart, 1992. ISBN 3476460096.

STÄHLI, A. MBA-Ausbildung: Inhalte, Methoden, Ziele. io Management Zeitschrift. 1990, vol. 59, issue $7 / 8$, pp. 39-42.

TURPIN (n.d.). The Future of Executive Education Trends in the industry, implications for IMD and leaders in learning and development. 6. 9. 2011.

ULRICH, P.; FLURI, E. Management. 5. ed. Bern; Stuttgart, 1988. ISBN 3825203751.

UNKLES, J. New directions for executive education and development. Journal of Banking and Financial Services. 2004, Oct-Nov, pp. 3.

VOSS, A.; HÄRING, K.; WELGE, M. K. Der Wettlauf mit dem Wandel: Management-Entwicklung im Umbruch. In WELGE, M. K.; HÄRING, K.; VOSS, A. (ed.). Management Development - Praxis, Trends und Perspektiven. Stuttgart, 2000, pp. 3-23. ISBN 3791015605.

WEBER, A. Auswahl externer Weiterbildungsveranstaltungen für obere Führungskräfte: Analyse des Zielsystems und des Auswahlverhaltens von oberen und obersten Führungskräften in deutschen Großunternehmen. München; Mering, 1997. ISBN 978-3-87988-264-9.

WEBER, W. Fortbildung für Führungskräfte. In KIESER, A.; REBER, G.; WUNDERER, R. (ed.). Handwörterbuch der Führung. Stuttgart, 1987, column 315-326. ISBN 3-7910-8028-8. 


\title{
EXECUTIVE DEVELOPMENT PROGRAMMES - REQUIREMENTS AND SUCCESS FACTORS
}

\begin{abstract}
The article deals with the requirements placed on Executive Development Programmes (EDPs) and their success factors. Executives belong to the top and upper management of companies who see the organization as a unit and not the individual function areas in the foreground. EDPs seek qualification that goes beyond the skills of their current activities, they offer practical state-of-the-art training to acquire new techniques, and they benefit from the experience of other participants. Further education institutions have to satisfy the demand for teaching technical, conceptual and social skills in compliance with the requirements of the learning process and type of content. Selection criteria for an alternative training or a specific school are, in general, content, target group and existing own resources. Using a practice-induced model, interdependent success factors of EDPs were identified such as provider quality, experiential learning and internationality, applied approach and environmental conditions.
\end{abstract}

Keywords: executives, executive education, executive education programmes, selection criteria, success factors

JEL Classification: A29/I21

CIHELKOVÁ, E. a kol. Evropská ekonomická integrace: procesy, politiky, governance. 1. vyd. Praha : VŠE, Nakladatelství Oeconomica, 2011. 336 s. ISBN 978-80-245-1835-0.

Evropská unie představuje nejhlubší formu ekonomické integrace ve světové ekonomice. Doposud byla často vnímána jako př́klad pro regionální seskupení ostatních zemí, avšak vlivem globalizace světové ekonomiky a současné krize se tato percepce mění. Dosavadní stupeň integrace může být při daných společných nástrojích a odlišných ekonomických charakteristikách členských zemí rizikem pro jejich udržitelný ekonomický rozvoj. Zejména v souvislosti s finanční a ekonomickou krizí členské státy řeší, jakým způsobem zlepšit fungování Unie a nastavit novou podobu ekonomické governance. V dané souvislosti tato kniha nabízí komplexní pohled na evropský integrační proces a jeho reakce na vývoj ve světě. Poskytuje teoretický rámec k zachycení hlavních trendů regionální ekonomické integrace; uvádí stěžejní milníky integrace na evropském kontinentě jako nástroj k porozumění příčinám, logice, resp. chronologické návaznosti změn v integračních procesech; zkoumá proměňující se institucionální rámec EU, včetně úlohy klíčových orgánů v jejím rozhodovacím procesu; charakterizuje možnosti využití a problémy evropského rozpočtu jako nástroje aktivit EU a př́stupy členských států; analyzuje jednotlivé integrační činnosti, týkající se jak vnitřních ekonomických záležitostí Unie $-\mathrm{s}$ důrazem na vnitřní trh a hospodářskou a měnovou unii, tak vnějších ekonomických vztahů. Závěrem je bilancován adaptační proces, kterým musely projít nové členské země po vstupu do EU v roce 2004 a 2007. 